\title{
The Role of BDNF as a Mediator of Neuroplasticity in Bipolar Disorder
}

\author{
Iria Grande ${ }^{1,3}$, Gabriel Rodrigo Fries ${ }^{1}$, Mauricio Kunz ${ }^{1}$ and Flavio Kapczinski ${ }^{1,2}{ }^{凶}$ \\ ${ }^{1}$ Bipolar Disorder Program and Laboratory of Molecular Psychiatry, Hospital de Clínicas de Porto Alegre, \\ Federal University of Rio Grande do Sul, Porto Alegre, Brazil \\ ${ }^{2}$ National Institute for Translational Medicine, INCT-TM, Porto Alegre, Brazil \\ ${ }^{3}$ Bipolar Disorders Program, Hospital Clinic, University of Barcelona, IDIBAPS, CIBERSAM, Barcelona, Spain
}

The cognitive impairment and neuroanatomical changes that takes place among patients with bipolar disorder (BD) patients has been well described. Recent data suggest that changes in neuroplasticity, cell resilience and connectivity are the main neuropathological findings in BD. Data from differential lines of research converges to the brain-derived neurotrophic factor (BDNF) as an important contributor to the neuroplasticity changes described among BD patients. BDNF serum levels have been shown to be decreased in depressive and manic episodes, returning to normal levels in euthymia. BDNF has also been shown to decrease as the disorder progresses. Moreover, factors that negatively influence the course of $\mathrm{BD}$, such as life stress and trauma have been shown to be associated with a decrease in BDNF serum levels. These findings suggest that BDNF plays a central role in the progression of BD. The present review discusses the role of BDNF as a mediator of the neuroplastic changes that occur in portion with mood episodes and the potential use of serum BDNF as a biomarker in BD.

Psychiatry Investig 2010;7:243-250

Key Words Bipolar disorder, Brain-derived neurotrophic factor, Neuroplasticity, Stress, Neurotrophins.

\section{INTRODUCTION}

Bipolar disorder (BD) is a highly disabling chronic mood disorder characterized by the presence of manic and depressive symptoms and a lifetime prevalence of $3.9 \%{ }^{1,2}$ Epidemiological studies indicate a role for both biological and environmental factors in the ethiopathogenesis of BD. Due to the high heritability and familial relative risk reported in $\mathrm{BD}$, there is little doubt that molecular genetics play an important role. However, the genetic basis for this illness remains elusive. ${ }^{3,4}$ An emerging body of evidence suggests that environmental stressors may trigger mood episodes. ${ }^{5}$ Indeed, it is known that stressors are more likely to be involved in the precipitation of the first episodes, but less so with subsequent episodes. ${ }^{6.7}$ In the same vein, cognitive impair-

Received: July 26, 2010 Accepted: September 7, 2010

Available online: December 15, 2010

$\triangle$ Correspondence: Flavio Kapczinski, MD, PhD

Bipolar Disorder Program and Laboratory of Molecular Psychiatry, Hospital de Clínicas de Porto Alegre, Av Ramiro Barcelos 2350, 90035-903, Porto Alegre RS, Brazil

Tel: +55-51-33598845, Fax: +55-51-33598846, E-mail: kapcz@terra.com.br

(a) This is an Open Access article distributed under the terms of the Creative Commons Attribution Non-Commercial License (http://creativecommons.org/licenses/bync/3.0) which permits unrestricted non-commercial use, distribution, and reproduction in any medium, provided the original work is properly cited. ment has been also demonstrated in bipolar patients with a history of multiple mood episodes. ${ }^{8}$ In terms of neuropathological findings, data suggest that changes in neuronal plasticity, particularly in cell resilience and connectivity, are the main finding in BD. ${ }^{9}$

The brain-derived neurotrophic factor (BDNF) plays an important role in a variety of neural processes during the development of both animals and humans. Initially, BDNF is important for neurogenesis, neuronal survival, and normal maturation of neural development pathways. In the adult, BDNF is not only important for synaptic plasticity and dendritic growth, but also for long-tem memory consolidation. ${ }^{10}$

In the present review, we describe the recent findings in the gene expression and mechanisms of action of BDNF as well as how psychosocial stress and $\mathrm{BD}$ mood episodes modulate $\mathrm{BD}$ NF brain levels. We also discuss the proposal of BDNF as a potential biomarker in $\mathrm{BD}$.

\section{BDNF GENE EXPRESSION AND MECHANISM OF ACTION}

BDNF is a member of the growth factor family, which is involved in promoting synaptic efficacy, neuronal connectivity 
and neuroplasticity. ${ }^{6}$ It has emerged as a key mediator of synaptic plasticity, neuronal connectivity and dendritic arborization. ${ }^{11,12}$ Together with other biological factors, such as neurotransmitters, hormones and other neurotrophins, BDNF orchestrates mechanisms of neuronal plasticity and survival.

\section{Transcription}

BDNF has an extremely complex genomic structure. The human gene presents eleven exons and nine functional promoters, producing up to seventeen different transcripts which encode for the same protein. ${ }^{14}$ In the rat, for instance, $B d n f$ gene has nine exons with its own promoter, producing nine different transcripts. ${ }^{15}$ Such a complex set of genomic promoters is thought to mediate accurate control of BDNF production. Cumulative evidence indicates that these transcripts are differentially distributed across brain regions in different cell types and even within different parts of the neuron. For example, in the rat, exon III transcripts are detected only in cell bodies, whereas exon IV transcripts are found in cell bodies and dendritic processes of visual cortex neurons. ${ }^{16}$ These promoters are differentially activated in response to diverse and varied signaling events, including epigenetic regulation. Recent reports have suggested a pathophysiological role for BDNF in major depression and suicide. ${ }^{17}$ Kim et al. 2010 have suggested that the BDNF messenger RNA (mRNA) expression is reduced in peripheral blood mononuclear cells of patients with major depression. This alteration of BDNF mRNA expression was more pronounced in recent suicide attempters.

There is evidence showing that chromatin remodeling involving the $B D N F$ gene may be associated with the deleterious effects of stress and with antidepressant response. More specifically, Tsankova et al..$^{18}$ found that chronic defeat stress, a mouse model of depression, induced a 3-fold downregulation of Bdnf mRNA expression in the hippocampus, an effect that was mediated by repressive histone methylation and consequent decrease in the expression of $B d n f$ transcripts III and IV. Moreover, chronic treatment with imipramine increased histone acetylation at these same promoters, thereby normalizing the expression of $B d n f$ transcripts III and IV and total protein. More recently, Yasuda et al. ${ }^{19}$ showed that the mood stabilizers lithium and valproate increased $B d n f$ transcript III in rat cortical neuronal cultured cells. Together, these studies strongly suggest that the regulation of $B D N F$ transcription may be a key target for the effects of antidepressants and mood stabilizers.

\section{Translational and post-translational modifications}

$B D N F$ transcripts are translated into proBDNF, which binds to sortilin in the Golgi to facilistate its appropriate folding, trafficking and secretion (Figure 1)..$^{20,21}$

It has been demonstrated that a single nucleotide polymor-

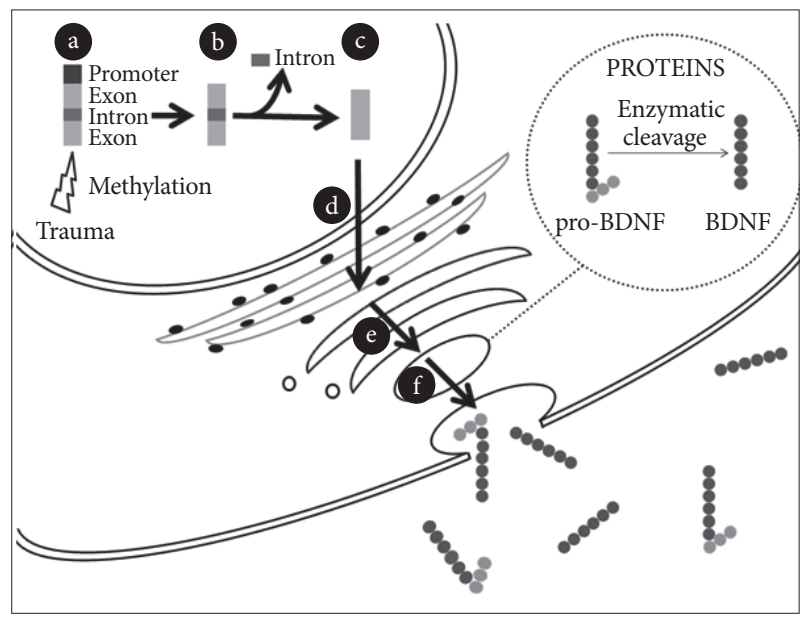

Figure 1. BDNF synthesis and release from neurons. a: BDNF gene: promoters, exons and introns. The BDNF gene expression may be modulated by epigenetic mechanisms. Trauma can induce methylation of the promoters of the BDNF gene and therefore inhibit their transcription. b: Different mRNA transcripts can be produced depending on which of the promoters is activated. c: An alternative splicing mechanism removes the introns out and leads to the formation of a processed mRNA molecule ready to be translated. d: The mRNA molecule translocates out of the nucleus into the cytoplasm and is translated into proBDNF in the endoplasmic reticulum. e: The newly synthesized proBDNF heads to the Golgi apparatus and is then cleaved into mature BDNF by endoproteases. f: BDNF-containing vesicles merge to the cell membrane in a $\mathrm{Ca}^{2+}$-dependent way and release $\mathrm{BDNF}$ to the extracellular space.

phism in the $B D N F$ gene, substitution of a valine for a methionine at the codon 66 (val66met), is involved in altered trafficking of BDNF. Such change seem to take place due to a reduced interaction of BDNF and sortilin inducing metBDNF aggregation to the cell body of neurons and thus preventing it to interact with synaptophysin. That would in turn reduce the BDNF secretion into the synapse. ${ }^{20}$ Further, knock-in $B D N F^{\text {metmet }}$ mice have abnormal dendritic arborization in the dentate gyrus and display anxious-related behaviors that are not normalized by antidepressant treatment. ${ }^{22}$ In $\mathrm{BD}$ patients, the val66met substitution in the $B D N F$ gene has been associated with impaired cognitive performance, ${ }^{23}$ and suicidal behavior. ${ }^{24}$ It has also been reported a differential response to lithium prophylaxis ${ }^{25}$ and decreased prefrontal cortical volume among patients with $\mathrm{BP}$ who presented the val66met substitution in the BDNF gene. ${ }^{26}$ In addition, val66val genotype showed an association with increased risk of rapid cycling ${ }^{27,28}$ and childhood onset of $\mathrm{BD} .{ }^{29,30}$ Serum levels of BDNF have also been evaluated in euthymic patients with both val/val and met carriers as compared to controls. ${ }^{31}$ The val66met was not associated with a differential serum level in $\mathrm{BD}$ patients.

The BDNF secretion can be either constitutive or, more frequently, regulated by stimuli. ${ }^{32}$ This activity-dependent secretion, a feature characteristic of BDNF and not of any other neurotrophin or growth factor, ${ }^{33}$ may be an important factor in mood 
regulation. Along with slow effects that require protein synthesis, BDNF exerts rapid signaling events that regulate synaptic plasticity. ${ }^{34}$ For example, inducing phosphorylation of synapsin and thereby increasing glutamate and GABA release. ${ }^{35} \mathrm{BDNF}$ can also increase ion influx through $\mathrm{N}$-methyl-D-aspartate receptors and then synaptic strength. ${ }^{36}$ Thus, BDNF is able to regulate synaptic plasticity and recent findings suggest that mood disorders would be associated with alterations in information processing within neural networks. ${ }^{37}$ A large proportion of neuronal BDNF is secreted in the pro-form (proBDNF) which is subsequently converted to the mature form (mBDNF) by endoproteolytic cleavage. ${ }^{38}$ Lee et al. ${ }^{39}$ suggested that the extracellular conversion from premature into mature forms was achieved through serine protease plasmin and by selective matrix metalloproteinases. The study of the conversion of proBDNF into BDNF is a matter of importance since these structures elicit differential biological effects. For instance, proBDNF preferentially binds to pan-neurotrophin receptor $\mathrm{p} 75^{\mathrm{NTR}}$ related to apoptosis while mature BDNF acts at tyrosine kinase (Trk) type- $\mathrm{B}$ receptor. On the contrary to $\mathrm{p} 75^{\mathrm{NTR}}$, the BDNF binding to the Trk B receptor initiates intracellular cascades involved with cellular survival, growth and differentiation via mitogenactivated protein kinase, phosphatidylinositol 3-kinase, and phospholipase C-g signal transduction pathways. ${ }^{37}$ They can induce dendritic sprouting by means of cytoskeleton modula$\operatorname{tion}^{40}$ (Figure 2). These findings have led to the "ying-yang hypothesis" where pro- and mature neurotrophins draw out opposite biological actions by means of differential receptors. ${ }^{21}$ The mature BDNF is critical for long-term potentiation, whereas proBDNF facilitates long-term depression. ${ }^{41}$ Depending on the localization, these molecules may display opposite effects. Intrahippocampal infusion of BDNF produces antidepressant effects, whereas it may present a pro-depressive role when the infusion is carried out in the ventral tegmental area/nucleus accumbens reward system. ${ }^{42}$

\section{PSYCHOSOCIAL STRESS, BIPOLAR DISORDER AND BDNF}

BDNF expression has been shown to be regulated by stress responsive corticosteroids. ${ }^{43}$ The interaction between BDNF and corticosteroids appears to play a key role in the environmentally-mediated vulnerability to psychopathology. ${ }^{44}$ Early exposure to traumatic life events and posttraumatic stress disorder, as well as depression, has been associated with hypothalamic-pituitary adrenal (HPA) axis dysfunction and enduring stress response alterations. ${ }^{45}$ In fact, Schüle and colleagues ${ }^{46}$ showed that patients with BDNF met/met polymorphism had higher HPA axis activity during dexametasone/CRH test. Glucocorticoids and mediators of stress interact with neurotransmitter systems result-

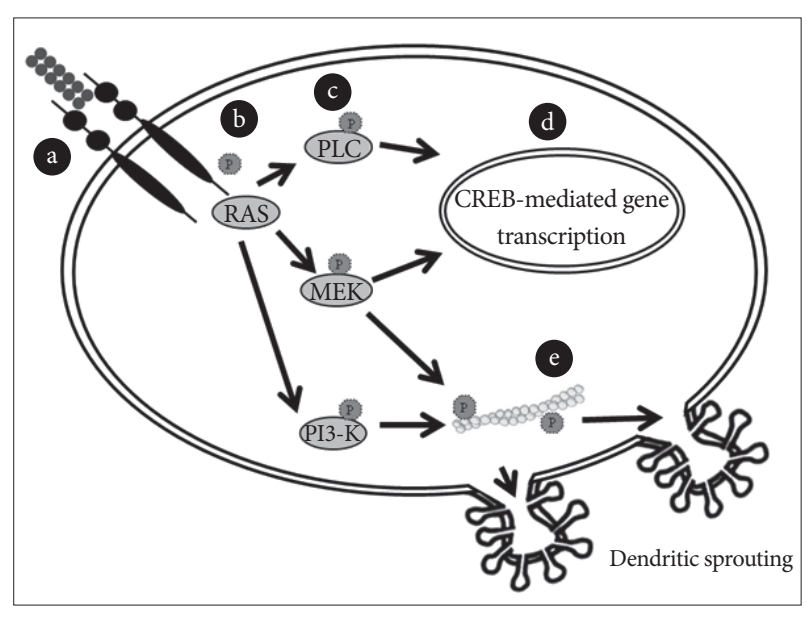

Figure 2. BDNF-activated transduction pathways induce dendritic sprouting. a: BDNF binds to tyrosine kinase receptor type-B and induces the dimerization of the receptor. $b$ : Binding of BDNF induces TrkB autophosphorylation at specific tyrosine residues of the receptor and thus creates binding sites for specific proteins. c: Three main intracellular signalling cascades are activated by TrkB: Rasmitogen-activated protein kinase (MAPK) pathway, the phosphatidylinositol 3-kinase (PI3K)-Akt pathway and the PLCg-Ca ${ }^{2+}$ pathway. d: Activation of PLC-g leads to the release of calcium from the endoplasmic reticulum and to activation of a calcium-calmodulindependent kinase II (CAMKII), ending in phosphorylation of CREB and activation of transcription. Activation of the MAPK pathway can also regulate transcription through phosphorylation of CREB. e: Signaling pathways mediate BDNF-promoted modifications of dendritic morphology. Simultaneous triggering of the PI3K and MAPK pathways concurrently alters both actin and microtubule dynamics and changes downstream dendrite branching.

ing in neuroplastic alterations seen in hippocampus, amygdala and prefrontal cortex. ${ }^{47}$ For instance, chronic stress in animal models is related to abnormal neuronal remodeling in the prefrontal cortex, ${ }^{48-50}$ particularly in glial cells, ${ }^{51}$ and amygdala. ${ }^{52}$

Accordingly, decreased BDNF levels have been associated with decreased hippocampal volume. Studies have reported smaller hippocampal volumes in patients with early life stress and child sexual abuse. Depressed women with a history of child abuse have an $18 \%$ smaller left hippocampal volume than nonabused women. ${ }^{53}$ Remarkably, these apparent differences in hippocampal size may be reversible with antidepressant treatment, consistent with a function of neurotrophic factors in neural plasticity in the hippocampus. ${ }^{54}$ Taken together, these data suggest that BDNF-related neuronal plasticity may be an important mediator of the effects of psychosocial stress on psychopathology.

\section{Stress and bipolar disorder}

Chronic stress is known to induce hyperactivation of amygdala, enhancing amygdala-dependent unlearned fear, fear conditioning, and aggression. ${ }^{55}$ Similarly, many of the symptoms experienced by patients with BD appear to be associated with abnormalities in emotional processing which involve amygdale-related circuitry. In this same vein, an enlargement of the amygdala has been described as the most prominent abnormality 
in $\mathrm{BD}{ }^{56-59}$ In addition to structural changes in this circuitry, functional neuroimaging studies indicate increased activity in the amygdala during acute mood episodes ${ }^{60,61}$ and impairment in amygdala-dependent tasks, such as facial recognition tasks. ${ }^{62}$ Emotional memory has also been evaluated as an amygdala-related cognitive task. Contrary to controls, patients with BP had no enhancement of memory for the emotional content of the story and the subjective perception of the emotional impact of the emotional condition was significantly different from that of the neutral condition in controls but not in people with $\mathrm{BD} .{ }^{63}$ These findings suggest that amygdala and its related circuits seem to be overactive and dysfunctional in patients with $\mathrm{BD}$. It may be possible that the gate system to code experiences as stressful is overactive and defective in BD patients. ${ }^{64}$ Such malfunctioning would render bipolar patients more vulnerable to stress. It has been reported that childhood trauma associated to $\mathrm{BD}$ may lead to more complex psychopathological manifestations. $^{65,66}$

It is noteworthy that the same genes associated with $\mathrm{BD}$ have been also been implicated in decreased resilience to stress. BD$\mathrm{NF}$ and other neurotrophic factors are believed to counteract the negative impact of stress hormones on the hippocampal volume. ${ }^{67}$ Together, BDNF and corticosteroids may play a role in the environmentally mediated vulnerability to cognitive impairment in $\mathrm{BD} .{ }^{68}$ In a $\mathrm{BD}$ sample, those with history of traumatic experiences had lower serum BDNF which may be related to an incremented load of stress. ${ }^{69}$

\section{BDNF AS A BIOMARKER IN BIPOLAR DISORDER}

Diagnostic criteria, as well as other aspects of clinical management such as treatment monitoring, are still essentially based on clinical symptomatology. There is a clear need for biological markers as complements for diagnostic and prognostic assessments in order to improve our management of BD. Recent evidence suggests that BDNF might be a potential marker. ${ }^{85}$

\section{BDNF as a biomarker of neuronal dysfunction}

BDNF is highly expressed in the cerebral cortex and hippocampus, brain areas that are known to regulate complex brain functions such as memory and emotion. It has been demonstrated that BDNF plays a key role in long-term potentiation, one of the most accepted models of learning and memory. For instance, the administration of exogenous BDNF to genetically modified mice deficient in BDNF or its receptor TrkB rescue the impairment in LTP process. ${ }^{70}$ In addition, transgenic mice lacking BDNF or TrkB demonstrate poorer performance than their wild-type littermates in the Morris water maze, a hippocampaldependent spatial learning task. ${ }^{71}$ These and other studies sug- gest that abnormalities in the BDNF-signaling system might be implicated in the cognitive decline observed in certain neuropsychiatric disorders, such as $\mathrm{BD},{ }^{72}$ major depression ${ }^{73}$ and schizophrenia. $^{74}$

There is an emerging body of evidence indicating that BDNF is associated with the mechanism of action of antidepressants and mood stabilizers. ${ }^{75,76}$ In the cerebral cortex and hippocampus, it has been reported increased BDNF expression after chronic antidepressant treatment. ${ }^{73}$ Moreover, it was demonstrated that the blockage of BDNF-signaling with either a tyrosine receptor kinase inhibitor or a mitogen-activated extracellular regulated kinase (ERK) kinase/ERK inhibitor attenuated the antidepressant effects of $\mathrm{BDNF}^{77}$ In this same vein, the chronic administration of lithium and valproate increased BDNF content in the rat hippocampus and prefrontal cortex. ${ }^{78,79}$ In addition, the depressive behavior induced by social defeat stress in rats is prevented by blockage of BDNF in the ventral tegmental area. $^{42}$

Taken together, these observations suggest that decreased BDNF may be a marker of neuronal dysfunction, possibly mediating cognitive impairment, which can be reversed by proper treatment. Therefore, a deeper understanding about the molecular determinants involved in BDNF-signaling cascades may provide a means for monitoring treatment response and disease progression as well as the development of novel agents for the treatment of $\mathrm{BD}$.

\section{BDNF and mood episodes}

It has repeatedly been described that cognitive dysfunction in patients with $\mathrm{BD}$ is not only present during mania and depression but also in euthymia. ${ }^{8,80-82}$ Such cognitive impairment has been construed as a consequence of the cellular strain imposed by recurrent mood episodes. ${ }^{83-85}$ In this sense, the burden of repeated mood episodes would translate into episode recurrence, cognitive impairment, disability and premature death. ${ }^{83,86}$

Some growth factors, including BDNF, which are altered by stress, have been shown to be modified in $\mathrm{BD} .{ }^{10}$ It has been demonstrated that serum BDNF levels decrease during manic and depressive episodes in both treated and drug-free subjects when compared to normal controls and to unipolar depression and that BDNF levels are negatively correlated with severity of manic and depressive symptoms. ${ }^{87-90}$ Moreover, Tramontina et al. ${ }^{91}$ showed that BDNF levels of manic patients were lower than those of healthy controls and that the significant difference vanished after successful treatment. In the light of such data, the decrease of BDNF levels may be conceived as a statedependent biomarker of $\mathrm{BD}$ as reported in the meta-analysis of Lin. ${ }^{92}$ It has also been described that BDNF levels are decreased in chronic or late stage individuals with BD compared to early stages of the illness. ${ }^{93}$ Moreover, accelerated age-related decreased 
of BDNF was described. ${ }^{94}$ In addition, serum neurotrophin- $3,{ }^{95}$ neurotrophin 4/5 and glial cell line-derived neurotrophic factor levels ${ }^{96}$ were showed to be increased during acute mood episodes. ${ }^{95-97}$ Taken together, these findings suggest an orchestrated change in the pattern of neurotrophin expression during mood episodes. As the disorder progresses, this pattern seems to be altered even between episodes, suggesting a trait characteristic of later stages of illness, characterized by chronic subsyndromic symptomatology, cognitive impairment and functional decline. ${ }^{44}$

Changes in neurotrophins seem to occur in portion with changes in other biomarkers such as oxidative stress markers and molecules related to inflammation. ${ }^{98}$ Taking this into account, we have postulated that such systemic changes related to mood episodes would be better measured by a composite assessment of peripheral toxicity. Thus we have recent put forward the notion that a systemic toxicity index would be a useful construct as a means to assess peripheral changes in mood episodes. ${ }^{99}$

\section{CONCLUSION}

Recent evidence suggests that BDNF might be a potential state marker is BD. The fact that serum BDNF levels are decreased during manic and depressive episodes, strongly suggest that the normalization of BDNF levels may be associated with clinical stabilization. ${ }^{87-90}$ However, these assumptions are based on case-control studies. Few longitudinal studies have been developed up to the present day. ${ }^{91,104}$ Another limitation of this hypothesis is that it is based fundamentally in studies conducted with animal models or human peripheral blood, and the presumption that such findings might be occurring in the human brain needs to be confirmed. In this regard, a postmortem study showing that individuals under antidepressant medications at the time of death had higher hippocampal BDNF expression than individuals not on antidepressants ${ }^{105}$ further support the role of BDNF in the treatment of mood disorders. The development of specific ligands for TrkB receptors could be extremely valuable in future positron emission tomography studies in humans.

At the same time, it is not appropriate to rely only in episodic alterations to fully explain the pathophysiology of BD. Impairments in neuronal plasticity and resilience could be the neuropathological hallmark of $\mathrm{BD}$, corresponding to more enduring changes in the brain of patients. Morphometric studies have demonstrated that patients with BD have enlargement of third and lateral ventricles and reduced gray matter volumes of orbital and medial prefrontal cortices, ventral striatum and mesotemporal cortex, as well as an increase of the size of amygdale. ${ }^{7}$ Notably, it was reported that such neuroanatomical changes tend to be more pronounced with repeated episodes. ${ }^{100}$ Apart from neuroanatomical changes, impairment in cognitive func- tion has been also demonstrated in manic, depressed as well as euthymic bipolar patients..$^{80,81,101,102}$ Such impairment seems to be related to indicators of the severity of illness, such as the presence of psychotic symptoms, longer duration of illness and higher number of manic episodes. ${ }^{103}$

Several transversal and longitudinal brain imaging studies demonstrated that lithium treatment increases cerebral cortical gray matter content and hippocampal volume in patients with BD. ${ }^{106-111}$ It can be presumed that these findings may be related to neurotrophic effects of lithium, especially by increasing cerebral BDNF. ${ }^{108,109}$ This hypothesis is largely supported by studies in rodents showing that lithium, valproate and antidepressants increase BDNF levels in the hippocampus and prefrontal cortex, brain regions known to be involved with mood regulation. ${ }^{78,79}$ Thus, we believe that substances that are able to increase cerebral BDNF expression have the potential to affect human affective responses and exert mood stabilizing effects, and that this rationale should be included in the investigation of new treatment approaches. In this regard, recent new promising drugs in the field of $\mathrm{BD}$ such as protein kinase $\mathrm{C}$ inhibitors ${ }^{112}$ and glutamate modulators ${ }^{113}$ may regulate the expression of BDNF through downstream effects on transcriptional factors and gene expression.

Finally, genetics is another promising field of research with a potential to unravel individual differences in treatment response related to distinct genetic predisposition. For instance, while a recent study showed that the $B D N F$ val66met polymorphism is not associated with antidepressant-induced mania, ${ }^{114}$ another study found that individuals val/met for this polymorphism may be better responders to lithium prophylaxis. ${ }^{25} \mathrm{Ob}$ viously, longitudinal studies are necessary to better determine the role of the val66met polymorphism in treatment response. In addition, studies addressing the involvement of other single nucleotide polymorphisms of the BDNF gene, as well as the interaction between $B D N F$ and other functional genes are warranted.

\section{REFERENCES}

1. Kessler RC, Berglund P, Demler O, Jin R, Merikangas KR, Walters EE. Lifetime prevalence and age-of-onset distributions of DSM-IV disorders in the National Comorbidity Survey Replication. Arch Gen Psychiatry 2005;62:593-602.

2. Yatham LN, Kennedy SH, Schaffer A, Parikh SV, Beaulieu S, O’Donovan C, et al. Canadian Network for Mood and Anxiety Treatments (CANMAT) and International Society for Bipolar Disorders (ISBD) collaborative update of CANMAT guidelines for the management of patients with bipolar disorder: update 2009. Bipolar Disord 2009;11:225255.

3. Barnett JH, Smoller JW. The genetics of bipolar disorder. Neuroscience 2009;164:331-343.

4. Glahn DC, Almasy L, Barguil M, Hare E, Peralta JM, Kent JW Jr, et al. Neurocognitive endophenotypes for bipolar disorder identified in multiplex multigenerational families. Arch Gen Psychiatry 2010;67:168- 
177.

5. Dienes KA, Hammen C, Henry RM, Cohen AN, Daley SE. The stress sensitization hypothesis: understanding the course of bipolar disorder. J Affect Disord 2006;95:43-49.

6. Post RM. Kindling and sensitization as models for affective episode recurrence, cyclicity, and tolerance phenomena. Neurosci Biobehav Rev 2007;31:858-873.

7. Strakowski SM, Delbello MP, Adler CM. The functional neuroanatomy of bipolar disorder: a review of neuroimaging findings. Mol Psychiatry 2005;10:105-116.

8. Martínez-Arán A, Vieta E, Colom F, Torrent C, Sánchez-Moreno J, Reinares $\mathrm{M}$, et al. Cognitive impairment in euthymic bipolar patients: implications for clinical and functional outcome. Bipolar Disord 2004; 6:224-232.

9. Kim HW, Rapoport SI, Rao JS. Altered expression of apoptotic factors and synaptic markers in postmortem brain from bipolar disorder patients. Neurobiol Dis 2010;37:596-603.

10. Post RM. Role of BDNF in bipolar and unipolar disorder: clinical and theoretical implications. J Psychiatr Res 2007;41:979-990.

11. Martinowich K, Manji H, Lu B. New insights into BDNF function in depression and anxiety. Nat Neurosci 2007;10:1089-1093.

12. Kuipers SD, Bramham CR. Brain-derived neurotrophic factor mechanisms and function in adult synaptic plasticity: new insights and implications for therapy. Curr Opin Drug Discov Devel 2006;9:580-586.

13. Martinowich K, Hattori D, Wu H, Fouse S, He F, Hu Y, Fan G, et al. DNA methylation-related chromatin remodeling in activity-dependent BDNF gene regulation. Science 2003;302:890-893.

14. Pruunsild P, Kazantseva A, Aid T, Palm K, Timmusk T. Dissecting the human BDNF locus: bidirectional transcription, complex splicing, and multiple promoters. Genomics 2007;90:397-406.

15. Aid T, Kazantseva A, Piirsoo M, Palm K, Timmusk T. Mouse and rat BDNF gene structure and expression revisited. J Neurosci Res 2007; 85:525-535.

16. Pattabiraman PP, Tropea D, Chiaruttini C, Tongiorgi E, Cattaneo A, Domenici L. Neuronal activity regulates the developmental expression and subcellular localization of cortical BDNF mRNA isoforms in vivo. Mol Cell Neurosci 2005;28:556-570.

17. Lee BH, Kim YK. BDNF mRNA expression of peripheral blood mononuclear cells was decreased in depressive patients who had or had not recently attempted suicide. J Affect Disord 2010;125:369-373.

18. Tsankova NM, Berton O, Renthal W, Kumar A, Neve RL, Nestler EJ. Sustained hippocampal chromatin regulation in a mouse model of depression and antidepressant action. Nat Neurosci 2006;9:519-525.

19. Yasuda S, Liang M, Marinova Z, Yahyavi A, Chuang D. The mood stabilizers lithium and valproate selectively activate the promoter IV of brain-derived neurotrophic factor in neurons. Mol Psychiatry 2009;14:51-59.

20. Chen ZY, Ieraci A, Teng H, Dall H, Meng CX, Herrera DG, et al. Sortilin controls intracellular sorting of brain-derived neurotrophic factor to the regulated secretory pathway. J Neurosci 2005;25:6156-6166.

21. Lu B, Pang PT, Woo NH. The yin and yang of neurotrophin action. Nat Rev Neurosci 2005;6:603-614.

22. Chen ZY, Jing D, Bath KG, Ieraci A, Khan T, Siao CJ, et al. Genetic variant BDNF (Val66Met) polymorphism alters anxiety-related behavior. Science 2006;314:140-143.

23. Rybakowski JK, Borkowska A, Czerski PM, Skibińska M, Hauser J. Polymorphism of the brain-derived neurotrophic factor gene and performance on a cognitive prefrontal test in bipolar patients. Bipolar Disord 2003;5:468-472.

24. Kim B, Kim CY, Hong JP, Kim SY, Lee C, Joo YH. Brain-derived neurotrophic factor Val/Met polymorphism and bipolar disorder. Association of the Met allele with suicidal behavior of bipolar patients. Neuropsychobiology 2008;58:97-103.

25. Rybakowski JK, Suwalska A, Skibinska M, Szczepankiewicz A, Leszczynska-Rodziewicz A, Permoda A, et al. Prophylactic lithium response and polymorphism of the brain-derived neurotrophic factor gene. Phar- macopsychiatry 2005;38:166-170

26. Matsuo K, Walss-Bass C, Nery FG, Nicoletti MA, Hatch JP, Frey BN, et al. Neuronal correlates of brain-derived neurotrophic factor Val66Met polymorphism and morphometric abnormalities in bipolar disorder. Neuropsychopharmacology 2009;34:1904-1913.

27. Green EK, Raybould R, Macgregor S, Hyde S, Young AH, O’Donovan $\mathrm{MC}$, et al. Genetic variation of brain-derived neurotrophic factor (BDNF) in bipolar disorder: case-control study of over 3000 individuals from the UK. Br J Psychiatry 2006;188:21-25.

28. Müller DJ, de Luca V, Sicard T, King N, Strauss J, Kennedy JL. Brainderived neurotrophic factor (BDNF) gene and rapid-cycling bipolar disorder: family-based association study. Br J Psychiatry 2006;189:317-323.

29. Strauss J, Barr CL, George CJ, King N, Shaikh S, Devlin B, et al. Association study of brain-derived neurotrophic factor in adults with a history of childhood onset mood disorder. Am J Med Genet B Neuropsychiatr Genet 2004;131B:16-19.

30. Strauss J, Barr CL, George CJ, Devlin B, Vetró A, Kiss E, et al. Brain-derived neurotrophic factor variants are associated with childhood-onset mood disorder: confirmation in a Hungarian sample. Mol Psychiatry 2005; 10:861-867.

31. Tramontina J, Frey BN, Andreazza AC, Zandona M, Santin A, Kapczinski F. Val66met polymorphism and serum brain-derived neurotrophic factor levels in bipolar disorder. Mol Psychiatry 2007;12:230-231.

32. Waterhouse EG, Xu B. New insights into the role of brain-derived neurotrophic factor in synaptic plasticity. Mol Cell Neurosci 2009;42:81-89.

33. Mowla SJ, Pareek S, Farhadi HF, Petrecca K, Fawcett JP, Seidah NG, et al. Differential sorting of nerve growth factor and brain-derived neurotrophic factor in hippocampal neurons. J Neurosci 1999;19:2069-2080.

34. Blum R, Konnerth A. Neurotrophin-mediated rapid signaling in the central nervous system: mechanisms and functions. Physiology (Bethesda) 2005;20:70-78.

35. Jovanovic JN, Czernik AJ, Fienberg AA, Greengard P, Sihra TS. Synapsins as mediators of BDNF-enhanced neurotransmitter release. Nat Neurosci 2000;3:323-329.

36. Levine ES, Crozier RA, Black IB, Plummer MR. Brain-derived neurotrophic factor modulates hippocampal synaptic transmission by increasing N-methyl-D-aspartic acid receptor activity. Proc Natl Acad Sci U S A 1998;95:10235-10239.

37. Castrén E. Is mood chemistry? Nat Rev Neurosci 2005;6:241-246.

38. Mowla SJ, Farhadi HF, Pareek S, Atwal JK, Morris SJ, Seidah NG, et al. Biosynthesis and post-translational processing of the precursor to brain-derived neurotrophic factor. J Biol Chem 2001;276:12660-12666.

39. Lee R, Kermani P, Teng KK, Hempstead BL. Regulation of cell survival by secreted proneurotrophins. Science 2001;294:1945-1948.

40. Georges PC, Hadzimichalis NM, Sweet ES, Firestein BL. The yin-yang of dendrite morphology: unity of actin and microtubules. Mol Neurobiol 2008;38:270-284.

41. Nagappan G, Zaitsev E, Senatorov VV Jr, Yang J, Hempstead BL, Lu B. Control of extracellular cleavage of ProBDNF by high frequency neuronal activity. Proc Natl Acad Sci U S A 2009;106:1267-1272.

42. Eisch AJ, Bolaños CA, de Wit J, Simonak RD, Pudiak CM, Barrot M, et al. Brain-derived neurotrophic factor in the ventral midbrain-nucleus accumbens pathway: a role in depression. Biol Psychiatry 2003;54: 994-1005.

43. Smith MA, Makino S, Kvetnansky R, Post RM. Stress and glucocorticoids affect the expression of brain-derived neurotrophic factor and neurotrophin-3 mRNAs in the hippocampus. J Neurosci 1995;15:17681777.

44. Manji HK, Quiroz JA, Sporn J, Payne JL, Denicoff K, A Gray N, et al. Enhancing neuronal plasticity and cellular resilience to develop novel, improved therapeutics for difficult-to-treat depression. Biol Psychiatry 2003;53:707-742.

45. Duval F, Crocq MA, Guillon MS, Mokrani MC, Monreal J, Bailey P, et al. Increased adrenocorticotropin suppression after dexamethasone administration in sexually abused adolescents with posttraumatic stress dis- 
order. Ann N Y Acad Sci 2004;1032:273-275.

46. Schüle C, Zill P, Baghai TC, Eser D, Zwanzger P, Wenig N, et al. Brainderived neurotrophic factor Val66Met polymorphism and dexamethasone/CRH test results in depressed patients. Psychoneuroendocrinology 2006;31:1019-1025.

47. McEwen BS. From molecules to mind. Stress, individual differences, and the social environment. Ann N Y Acad Sci 2001;935:42-49.

48. Maroun M. Stress reverses plasticity in the pathway projecting from the ventromedial prefrontal cortex to the basolateral amygdala. Eur J Neurosci 2006;24:2917-2922.

49. Jay TM, Rocher C, Hotte M, Naudon L, Gurden H, Spedding M. Plasticity at hippocampal to prefrontal cortex synapses is impaired by loss of dopamine and stress: importance for psychiatric diseases. Neurotox Res 2004;6:233-244.

50. Brown SM, Henning S, Wellman CL. Mild, short-term stress alters dendritic morphology in rat medial prefrontal cortex. Cereb Cortex 2005; 15:1714-1722.

51. Czéh B, Simon M, Schmelting B, Hiemke C, Fuchs E. Astroglial plasticity in the hippocampus is affected by chronic psychosocial stress and concomitant fluoxetine treatment. Neuropsychopharmacology 2006; 31:1616-1626.

52. Vyas A, Bernal S, Chattarji S. Effects of chronic stress on dendritic arborization in the central and extended amygdala. Brain Res 2003;965: 290-294.

53. Vythilingam M, Heim C, Newport J, Miller AH, Anderson E, Bronen $\mathrm{R}$, et al. Childhood trauma associated with smaller hippocampal volume in women with major depression. Am J Psychiatry 2002;159:20722080.

54. Rattiner LM, Davis M, Ressler KJ. Brain-derived neurotrophic factor in amygdala-dependent learning. Neuroscientist 2005;11:323-333.

55. McEwen BS. Protection and damage from acute and chronic stress: allostasis and allostatic overload and relevance to the pathophysiology of psychiatric disorders. Ann N Y Acad Sci 2004;1032:1-7.

56. DelBello MP, Zimmerman ME, Mills NP, Getz GE, Strakowski SM. Magnetic resonance imaging analysis of amygdala and other subcortical brain regions in adolescents with bipolar disorder. Bipolar Disord 2004;6:43-52.

57. Blumberg HP, Fredericks C, Wang F, Kalmar JH, Spencer L, Papademetris X, et al. Preliminary evidence for persistent abnormalities in amygdala volumes in adolescents and young adults with bipolar disorder. Bipolar Disord 2005;7:570-576.

58. Altshuler LL, Bartzokis G, Grieder T, Curran J, Jimenez T, Leight K, et al. An MRI study of temporal lobe structures in men with bipolar disorder or schizophrenia. Biol Psychiatry 2000;48:147-162.

59. Vieta E, Phillips ML. Deconstructing bipolar disorder: a critical review of its diagnostic validity and a proposal for DSM-V and ICD-11. Schizophr Bull 2007;33:886-892.

60. Yurgelun-Todd DA, Gruber SA, Kanayama G, Killgore WD, Baird $\mathrm{AA}$, Young AD. fMRI during affect discrimination in bipolar affective disorder. Bipolar Disord 2000;2:237-248.

61. Malhi GS, Lagopoulos J, Owen AM, Yatham LN. Bipolaroids: functional imaging in bipolar disorder. Acta Psychiatr Scand Suppl 2004: 46-54.

62. Chen CH, Lennox B, Jacob R, Calder A, Lupson V, Bisbrown-Chippendale R, et al. Explicit and implicit facial affect recognition in manic and depressed States of bipolar disorder: a functional magnetic resonance imaging study. Biol Psychiatry 2006;59:31-39.

63. Kauer-Sant'anna M, Yatham LN, Tramontina J, Weyne F, Cereser KM, Gazalle FK, et al. Emotional memory in bipolar disorder. Br J Psychiatry 2008;192:458-463.

64. Phillips ML, Vieta E. Identifying functional neuroimaging biomarkers of bipolar disorder: toward DSM-V. Schizophr Bull 2007;33:893-904.

65. Leverich GS, Post RM. Course of bipolar illness after history of childhood trauma. Lancet 2006;367:1040-1042.

66. Garno JL, Goldberg JF, Ramirez PM, Ritzler BA. Impact of childhood abuse on the clinical course of bipolar disorder. Br J Psychiatry 2005; 186:121-125.

67. Manji HK, Quiroz JA, Payne JL, Singh J, Lopes BP, Viegas JS, et al. The underlying neurobiology of bipolar disorder. World Psychiatry 2003; 2:136-146.

68. Kawashima H, Numakawa T, Kumamaru E, Adachi N, Mizuno H, Ninomiya M, et al. Glucocorticoid attenuates brain-derived neurotrophic factor-dependent upregulation of glutamate receptors via the suppression of microRNA-132 expression. Neuroscience 2010;165:1301-1311.

69. Kauer-Sant'Anna M, Tramontina J, Andreazza AC, Cereser K, da Costa S, Santin A, et al. Traumatic life events in bipolar disorder: impact on BDNF levels and psychopathology. Bipolar Disord 2007;9 Suppl 1: 128-135.

70. Patterson SL, Pittenger C, Morozov A, Martin KC, Scanlin H, Drake C, et al. Some forms of cAMP-mediated long-lasting potentiation are associated with release of BDNF and nuclear translocation of phosphoMAP kinase. Neuron 2001;32:123-140.

71. Minichiello L, Korte M, Wolfer D, Kühn R, Unsicker K, Cestari V, et al. Essential role for TrkB receptors in hippocampus-mediated learning. Neuron 1999;24:401-414.

72. Shaltiel G, Chen G, Manji HK. Neurotrophic signaling cascades in the pathophysiology and treatment of bipolar disorder. Curr Opin Pharmacol 2007;7:22-26.

73. Schmidt HD, Banasr M, Duman RS. Future Antidepressant Targets: Neurotrophic Factors and Related Signaling Cascades. Drug Discov Today Ther Strateg 2008;5:151-156.

74. Egan MF, Kojima M, Callicott JH, Goldberg TE, Kolachana BS, Bertolino A, et al. The BDNF val66met polymorphism affects activity-dependent secretion of BDNF and human memory and hippocampal function. Cell 2003;112:257-269.

75. Coyle JT, Duman RS. Finding the intracellular signaling pathways affected by mood disorder treatments. Neuron 2003;38:157-160.

76. Castrén E, Rantamäki T. The role of BDNF and its receptors in depression and antidepressant drug action: Reactivation of developmental plasticity. Dev Neurobiol 2010;70:289-297.

77. Saarelainen T, Hendolin P, Lucas G, Koponen E, Sairanen M, MacDonald $\mathrm{E}$, et al. Activation of the $\operatorname{TrkB}$ neurotrophin receptor is induced by antidepressant drugs and is required for antidepressant-induced behavioral effects. J Neurosci 2003;23:349-357.

78. Frey BN, Andreazza AC, Ceresér KM, Martins MR, Valvassori SS, Réus GZ, et al. Effects of mood stabilizers on hippocampus BDNF levels in an animal model of mania. Life Sci 2006;79:281-286.

79. Fukumoto T, Morinobu S, Okamoto Y, Kagaya A, Yamawaki S. Chronic lithium treatment increases the expression of brain-derived neurotrophic factor in the rat brain. Psychopharmacology (Berl) 2001;158:100106.

80. Martínez-Arán A, Vieta E, Reinares M, Colom F, Torrent C, SanchezMoreno J, et al. Cognitive function across manic or hypomanic, depressed, and euthymic states in bipolar disorder. Am J Psychiatry 2004;161: 262-270.

81. Mur M, Portella MJ, Martínez-Arán A, Pifarré J, Vieta E. Persistent neuropsychological deficit in euthymic bipolar patients: executive function as a core deficit. J Clin Psychiatry 2007;68:1078-1086.

82. Robinson LJ, Thompson JM, Gallagher P, Goswami U, Young AH, Ferrier IN, et al. A meta-analysis of cognitive deficits in euthymic patients with bipolar disorder. J Affect Disord 2006;93:105-115.

83. Kapczinski F, Vieta E, Andreazza AC, Frey BN, Gomes FA, Tramontina J, et al. Allostatic load in bipolar disorder: implications for pathophysiology and treatment. Neurosci Biobehav Rev 2008;32:675-692.

84. Post RM. Transduction of psychosocial stress into the neurobiology of recurrent affective disorder. Am J Psychiatry 1992;149:999-1010.

85. Kapczinski F, Frey BN, Kauer-Sant'Anna M, Grassi-Oliveira R. Brainderived neurotrophic factor and neuroplasticity in bipolar disorder. Expert Rev Neurother 2008;8:1101-1113.

86. Soreca I, Frank E, Kupfer DJ. The phenomenology of bipolar disorder: 
what drives the high rate of medical burden and determines long-term prognosis? Depress Anxiety 2009;26:73-82.

87. Cunha AB, Frey BN, Andreazza AC, Goi JD, Rosa AR, Goncalves CA, et al. Serum brain-derived neurotrophic factor is decreased in bipolar disorder during depressive and manic episodes. Neurosci Lett 2006;398: 215-219.

88. de Oliveira GS, Ceresér KM, Fernandes BS, Kauer-Sant'Anna M, Fries GR, Stertz L, et al. Decreased brain-derived neurotrophic factor in medicated and drug-free bipolar patients. J Psychiatr Res 2009;43:1171-1174.

89. Machado-Vieira R, Dietrich MO, Leke R, Cereser VH, Zanatto V, Kapczinski F, et al. Decreased plasma brain derived neurotrophic factor levels in unmedicated bipolar patients during manic episode. Biol Psychiatry 2007;61:142-144.

90. Fernandes BS, Gama CS, Kauer-Sant'Anna M, Lobato MI, Belmonte-deAbreu P, Kapczinski F. Serum brain-derived neurotrophic factor in bipolar and unipolar depression: a potential adjunctive tool for differential diagnosis. J Psychiatr Res 2009;43:1200-1204.

91. Tramontina JF, Andreazza AC, Kauer-Santanna M, Stertz L, Goi J, Chiarani $\mathrm{F}$, et al. Brain-derived neurotrophic factor serum levels before and after treatment for acute mania. Neurosci Lett 2009;452:111-113.

92. Lin PY. State-dependent decrease in levels of brain-derived neurotrophic factor in bipolar disorder: a meta-analytic study. Neurosci Lett 2009; 466:139-143.

93. Kauer-Sant'Anna M, Kapczinski F, Andreazza AC, Bond DJ, Lam RW, Young LT, et al. Brain-derived neurotrophic factor and inflammatory markers in patients with early- vs. late-stage bipolar disorder. Int J Neuropsychopharmacol 2009;12:447-458.

94. Yatham LN, Kapczinski F, Andreazza AC, Trevor Young L, Lam RW, Kauer-Santanna M. Accelerated age-related decrease in brain-derived neurotrophic factor levels in bipolar disorder. Int J Neuropsychopharmacol 2009;12:137-139.

95. Walz JC, Andreazza AC, Frey BN, Cacilhas AA, Ceresér KM, Cunha $A B$, et al. Serum neurotrophin-3 is increased during manic and depressive episodes in bipolar disorder. Neurosci Lett 2007;415:87-89.

96. Rosa AR, Frey BN, Andreazza AC, Ceresér KM, Cunha AB, Quevedo J, et al. Increased serum glial cell line-derived neurotrophic factor immunocontent during manic and depressive episodes in individuals with bipolar disorder. Neurosci Lett 2006;407:146-150.

97. Walz JC, Magalhães PV, Giglio LM, Cunha AB, Stertz L, Fries GR, et al. Increased serum neurotrophin- $4 / 5$ levels in bipolar disorder. J Psychiatr Res 2009;43:721-723.

98. Kim Y, Jung H, Myint A, Kim H, Park SH. Imbalance between pro-inflammatory and anti-inflammatory cytokines in bipolar disorder. J Affect Disord 2007;104:91-95.

99. Kapczinski F, Dal-Pizzol F, Teixeira AL, Magalhaes PV, Kauer-Sant’Anna $\mathrm{M}, \mathrm{Klamt} \mathrm{F}$, et al. A systemic toxicity index developed to assess peripheral changes in mood episodes. Mol Psychiatry 2010;15:784-786.

100. Strakowski SM, DelBello MP, Zimmerman ME, Getz GE, Mills NP, Ret J, et al. Ventricular and periventricular structural volumes in first- ver- sus multiple-episode bipolar disorder. Am J Psychiatry 2002;159:18411847.

101. Thompson JM, Gallagher P, Hughes JH, Watson S, Gray JM, Ferrier $\mathrm{IN}$, et al. Neurocognitive impairment in euthymic patients with bipolar affective disorder. Br J Psychiatry 2005;186:32-40.

102. Robinson LJ, Ferrier IN. Evolution of cognitive impairment in bipolar disorder: a systematic review of cross-sectional evidence. Bipolar Disord 2006;8:103-116.

103. Martinez-Aran A, Vieta E, Torrent C, Sanchez-Moreno J, Goikolea JM, Salamero M, et al. Functional outcome in bipolar disorder: the role of clinical and cognitive factors. Bipolar Disord 2007;9:103-113.

104. Palomino A, Vallejo-Illarramendi A, González-Pinto A, Aldama A, González-Gómez C, Mosquera F, et al. Decreased levels of plasma BDNF in first-episode schizophrenia and bipolar disorder patients. Schizophr Res 2006;86:321-322.

105. Chen B, Dowlatshahi D, MacQueen GM, Wang JF, Young LT. Increased hippocampal BDNF immunoreactivity in subjects treated with antidepressant medication. Biol Psychiatry 2001;50:260-265.

106. Moore GJ, Bebchuk JM, Wilds IB, Chen G, Manji HK. Lithium-induced increase in human brain grey matter. Lancet 2000;356:1241-1242.

107. Sassi RB, Nicoletti M, Brambilla P, Mallinger AG, Frank E, Kupfer DJ, et al. Increased gray matter volume in lithium-treated bipolar disorder patients. Neurosci Lett 2002;329:243-245.

108. Yucel K, Taylor VH, McKinnon MC, Macdonald K, Alda M, Young LT, et al. Bilateral hippocampal volume increase in patients with bipolar disorder and short-term lithium treatment. Neuropsychopharmacology 2008;33:361-367.

109. Yucel K, McKinnon MC, Taylor VH, Macdonald K, Alda M, Young LT, et al. Bilateral hippocampal volume increases after long-term lithium treatment in patients with bipolar disorder: a longitudinal MRI study. Psychopharmacology (Berl) 2007;195:357-367.

110. Bearden CE, Thompson PM, Dutton RA, Frey BN, Peluso MA, Nicoletti $\mathrm{M}$, et al. Three-dimensional mapping of hippocampal anatomy in unmedicated and lithium-treated patients with bipolar disorder. Neuropsychopharmacology 2008;33:1229-1238.

111. Bearden CE, Thompson PM, Dalwani M, Hayashi KM, Lee AD, Nicoletti $\mathrm{M}$, et al. Greater cortical gray matter density in lithium-treated patients with bipolar disorder. Biol Psychiatry 2007;62:7-16.

112. Zarate CA Jr, Singh JB, Carlson PJ, Quiroz J, Jolkovsky L, Luckenbaugh DA, et al. Efficacy of a protein kinase C inhibitor (tamoxifen) in the treatment of acute mania: a pilot study. Bipolar Disord 2007;9:561-570.

113. Zarate CA Jr, Quiroz JA, Singh JB, Denicoff KD, De Jesus G, Luckenbaugh DA, et al. An open-label trial of the glutamate-modulating agent riluzole in combination with lithium for the treatment of bipolar depression. Biol Psychiatry 2005;57:430-432.

114. Zai G, Mundo E, Strauss J, Wong GW, Kennedy JL. Brain-derived neurotrophic factor (BDNF) gene not associated with antidepressant-induced mania. Bipolar Disord 2007;9:521-525. 